\title{
Quantitative Multiplication of Mycobacterium lepraemurium in a Cell-free Liquid Medium (NC-5)
}

\author{
By M. NAKAMURA \\ Department of Microbiology, Kurume University School of Medicine, \\ Kurume, 830, Japan
}

(Received I9 July 1973; revised 29 January 1974)

\begin{abstract}
SUMMARY
Mycobacterium lepraemurium multiplies in a cell-free liquid medium, referred to as NC-5, which is enriched Kirchner medium plus goat serum, $\alpha$-ketoglutaric acid, cytochrome $c$, haemin, and L-cysteine. At $30{ }^{\circ} \mathrm{C}$, the bacilli gradually elongated before multiplying 100- to rooo-fold. The maximum number of bacilli is reached after 8 weeks' incubation. The generation time of Mycobacterium lepraemurium is between 8 and 14 days, depending upon the size of inoculum. Bacilli grown in NC-5 medium maintain their capacity to produce leprosy in mice. Optimum growth was with the basal medium at $\mathrm{pH} 7.3$ using a small number of bacilli in the inoculum.
\end{abstract}

\section{INTRODUCTION}

Nakamura (1972) briefly reported that Mycobacterium lepraemurium, which hitherto had been thought to be an obligate intracellular parasite, could multiply in a cell-free medium containing $\alpha$-ketoglutaric acid and cytochrome $c$. This culture medium was referred to as NC medium. Nakamura (1973) also noted that the bacilli multiplied more abundantly if haemin and $\mathrm{L}$-cysteine $\mathrm{HCl}$ were added to $\mathrm{NC}$ medium. The present paper describes some additional morphological and quantitative results as well as some factors involved in the multiplication of $M$. lepraemurium in this modified medium, which is referred to as $\mathrm{NC}-5$ medium.

\section{METHODS}

Bacterial suspension. Mycobacterium lepraemurium (M53-55), Hawaiian strain, was obtained from a subcutaneous leproma experimentally developed in a $\mathrm{C}_{3} \mathrm{H}$ mouse. After being gently minced with scissors, or ground in a sterile mortar in some cases, a bacillary suspension was made with sterile distilled water. A suspension containing an appropriate number of bacilli for morphologically observing and counting was prepared for use with sterile distilled water containing $0.1 \%$ bovine albumin $\mathrm{V}$ fraction (Armour). The suspension was kept for up to two weeks at $-20{ }^{\circ} \mathrm{C}$ until required.

Treatments with digestive enzymes and chemical agents. Each bacillary suspension was treated with trypsin, pronase and deoxycholate solution at final concentrations of $0.2,0 . I$ and $0.1 \%$, respectively, for $60 \mathrm{~min}$ at $37^{\circ} \mathrm{C}$. After treatment, the suspensions were centrifuged at $720 \mathrm{~g}$ for $30 \mathrm{~min}$ and the sediments resuspended in an appropriate volume of distilled water. This was mixed with an equal volume of chilled petroleum spirit (b.p. 40 to $70^{\circ} \mathrm{C}$ ) and then stood at $4{ }^{\circ} \mathrm{C}$ for $20 \mathrm{~h}$, after which the aqueous layer was taken for experimentation. As controls, a non-treated fresh bacillary suspension and a suspension 
treated under the same conditions used for enzymic digestion, i.e. held at $37^{\circ} \mathrm{C}$ for $60 \mathrm{~min}$, were prepared.

Partial purification of the bacilli. Mycobacterium lepraemurium was isolated from the leproma suspension and partially purified according to the method of Mori, Kosaka, Ito \& Nishimura (196I) modified by Nakamura \& Ueno (1963). After treatment with trypsin at $0.2 \%$ final concentration at $37^{\circ} \mathrm{C}$ for $30 \mathrm{~min}$, the coarse tissue fragments in the suspension were removed by low speed centrifuging and then the bacteria were collected by recentrifuging at $720 \mathrm{~g}$ for $30 \mathrm{~min}$. The sediment was suspended in distilled water and an equal volume of $\mathrm{I} \% \mathrm{NaOH}$ added. After centrifuging at $720 \mathrm{~g}$ for $30 \mathrm{~min}$, the sedimented bacteria were resuspended in sterile distilled water.

Composition and preparation of the culture medium ( $N C-5)$. Basal medium, referred to as EKP medium (enriched Kirchner-pantothenate medium; Kirchner, I932) contained $\mathrm{KH}_{2} \mathrm{PO}_{4}, 6.0 \mathrm{~g} ; \mathrm{Na}_{2} \mathrm{HPO}_{4}$. $\mathrm{I}_{2} \mathrm{H}_{2} \mathrm{O}, 6.0 \mathrm{~g}$; sodium citrate, $3.7 \mathrm{~g}$; sodium glutamate, $15.0 \mathrm{~g}$; $\mathrm{MgSO}_{4} .7 \mathrm{H}_{2} \mathrm{O}$, $0.9 \mathrm{~g}$; glycerol, $30.0 \mathrm{ml}$; glucose, $4.0 \mathrm{~g}$; sodium pyruvate, $5.0 \mathrm{~g}$; distilled water to $1000 \mathrm{ml}$; adjusted to $\mathrm{pH} 7.3$ with $20 \% \mathrm{NaOH}$, and then $20 \mathrm{ml}$ calcium pantothenate, $0.5 \%(\mathrm{w} / \mathrm{v})$ aqueous solution, added. This was autoclaved at $\mathrm{II} 5{ }^{\circ} \mathrm{C}$ for $\mathrm{IO} \mathrm{min}$. To 5 vol. sterile EKP medium was added aseptically I vol. goat serum (previously sterilized by heating at $58{ }^{\circ} \mathrm{C}$ for $30 \mathrm{~min}$ ), $0.5 \mathrm{vol} .2 \% \alpha$-ketoglutaric acid solution, one vol. $0.1 \%$ cytochrome $c$ solution, 0.5 vol. $0.04 \%$ haemin solution (prepared according to Biberstein \& Gills, I96I), and 0.2 vol. $0.3 \%$ L-cysteine $\mathrm{HCl}$ solution. Each solution was sterilized by filtration through Millipore filters. Medium was distributed aseptically in $8 \mathrm{ml}$ amounts into sterile test tubes $(\mathrm{I} 0.5 \times \mathrm{I} \cdot 3 \mathrm{~cm})$ fitted with sterile rubber stoppers and used immediately. EKP medium containing goat serum only (EKP-goat serum medium) was also prepared to act as control.

Assessment of the growth of bacilli. Bacterial growth was assessed either by a bacillary counting method (Nakamura, 1972) or a morphological observation method involving slide culture (Nakamura, I967, I973).

\section{RESULTS}

\section{Morphological features of cultivated $M$. lepraemurium}

Microscopic features of bacilli cultivated in NC-5 medium were observed periodically using the slide culture method (Fig. I). Bacilli gradually elongated during the first 2 weeks of incubation and then began to multiply until after 6 weeks' incubation forming a bacterial mass. This mass could be recognized macroscopically and was similar to that previously obtained using NC medium (Nakamura, 1972). No such turbid mass occurred when EKP-goat serum medium was used as control.

\section{Bacillary counting in culture medium}

The number of bacilli growing in NC-5 medium at $30^{\circ} \mathrm{C}$ increased approximately 32 -fold over 6 weeks' incubation and reached a maximum after 8 weeks, and then began to decrease (Fig. 2). The generation time of Mycobacterium lepraemurium can be calculated as 10.9 days.

\section{Factors influencing multiplication of bacilli in NC-5 medium}

Culture temperature. Bacilli cultivated at $37^{\circ} \mathrm{C}$ elongated more rapidly than they did at $30{ }^{\circ} \mathrm{C}$, but the number of lysed bacteria increased progressively with time. In most cases no turbid mass, resulting from extensive multiplication of bacilli, was recognized.

Serum for NC-5 medium. Of a variety of sera (bovine, horse, rabbit, goat, rat and bovine albumin $\mathrm{V}$ fraction) used in NC-5 medium, goat serum gave the most reproducible results. 

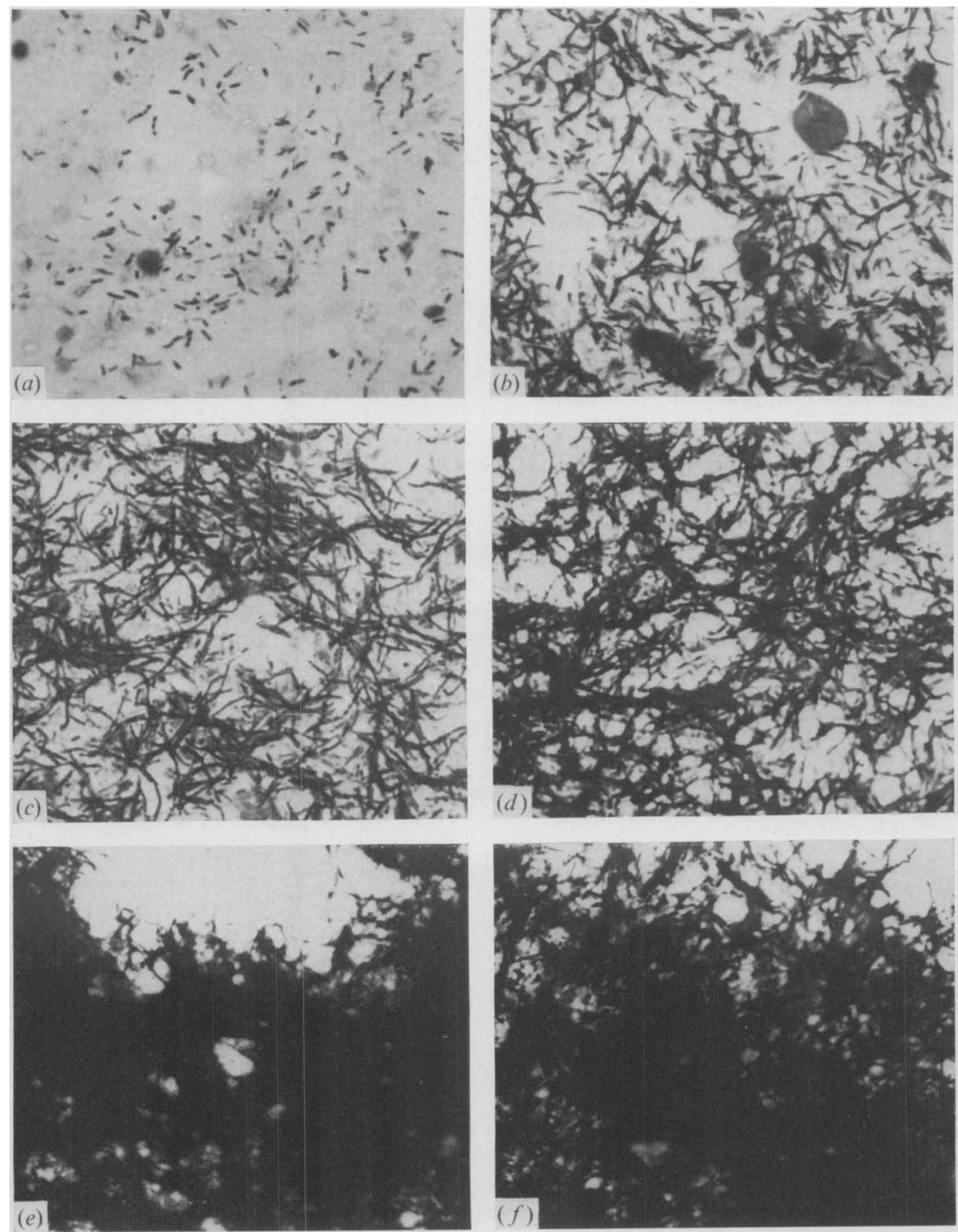

Fig. I. Microscopic feature of the starting material (a), and microscopic features of the bacilli cultivated in NC-5 medium at $30^{\circ} \mathrm{C}$ for $(b) 2$ weeks, $(c) 4$ weeks, $(d) 6$ weeks, $(e) 8$ weeks, $(f)$ Io weeks. 


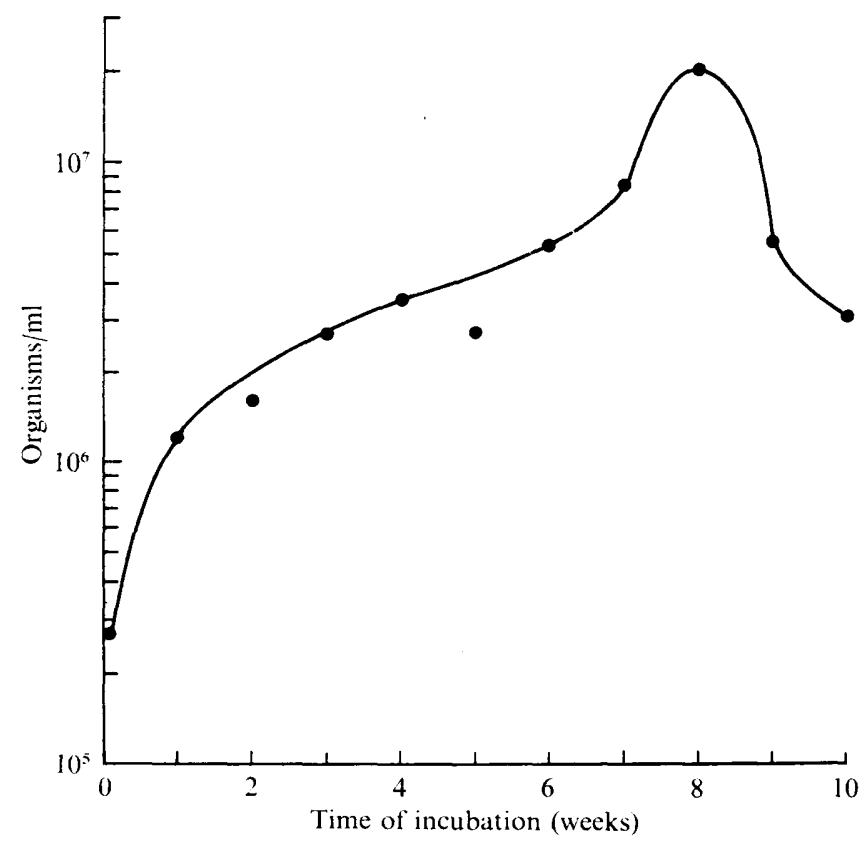

Fig. 2. Growth curve of Mycobacterium lepraemurium in NC-5 medium. Initial number of bacilli $/ \mathrm{ml}$ culture medium was $\mathrm{I} \cdot 7 \times 10^{5}$.

Table I. Effect of the $p H$ of the basal medium on the growth rate of Mycobacterium lepraemurium

$\begin{array}{ccc}\begin{array}{c}\text { Final pH of } \\ \text { Initial pH } \\ \text { of basal } \\ \text { medium }\end{array} & \begin{array}{c}\text { NC-5 medium } \\ \text { before } \\ \text { inoculation }\end{array} & \begin{array}{c}\text { Growth rates of } \\ \text { Mycobacterium } \\ \text { lepraemurium }\end{array} \\ 6.4 & 5.6 & + \\ 6 \cdot 7 & 5.9 & + \\ 7 \cdot 0 & 6.3 & +++ \\ 7.3 & 6.5 & ++++ \\ 7.6 & 6.6 & ++++ \\ 7.0 & 6.7 & + \\ 7.3 & 6.8 & ++++ \\ 7.6 & 6.8 & ++++ \\ 7.9 & 6.8 & +\end{array}$

The efficiency of bovine serum was also good but varied with different batches of preparation. Goat serum, at $10 \%$ of the final concentration, was sufficient to obtain a significant multiplication of bacilli.

Optimal pH of culture medium. The final pH of NC-5 medium varies with different batches of goat serum, which must be added aseptically, and it is thus difficult to adjust accurately. The effect of EKP basal medium at various $\mathrm{pH}$ values was therefore tested on the growth of bacilli using two different batches of goat serum. Significant and reproducible multiplication of bacilli occurred when the initial $\mathrm{pH}$ of the basal medium was $7 \cdot 3$ (Table 1 ).

Relationship between inoculum size and growth rate. A definite relationship was found between the amount of inoculum and the growth rate as well as the increase in numbers of bacilli in NC-5 medium: the smaller the inoculum the faster was the observed growth rate 


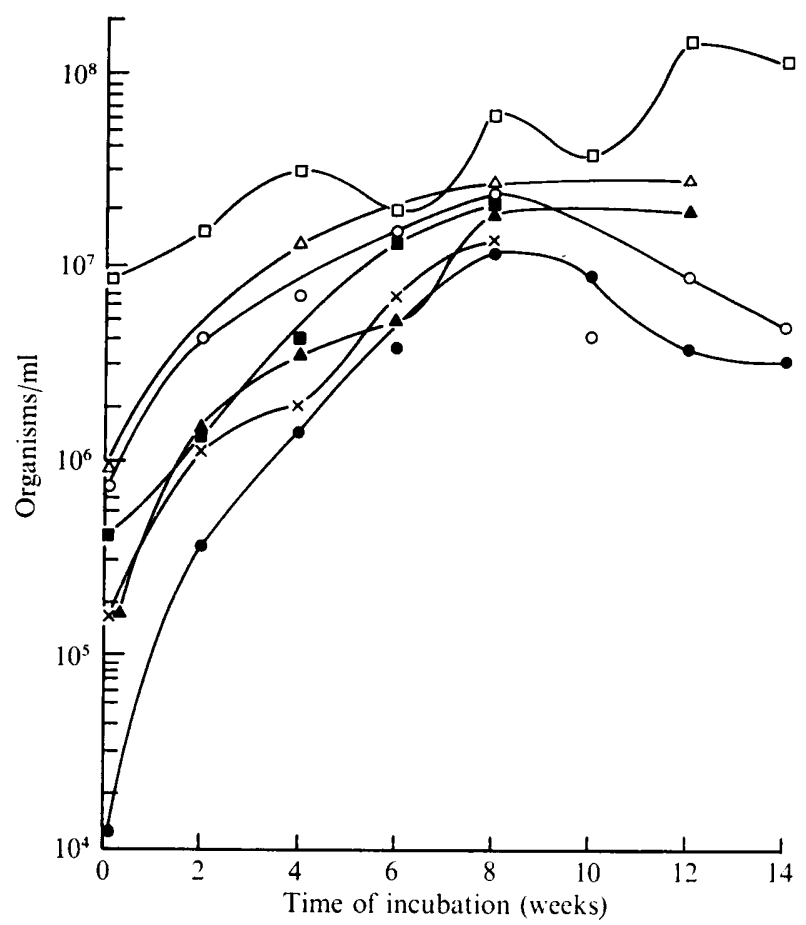

Fig. 3. Growth curves of Mycobacterium lepraemurium influenced by different inoculum sizes. Initial numbers of bacilli/ml culture medium were: $\bullet, 1 \cdot 2 \times 10^{4} ; \Delta, 1 \cdot 7 \times 10^{5} ; \times, 1 \cdot 7 \times 10^{5} ; \mathbf{m}, 4 \cdot 5$ $\times 10^{5} ; 0,7.4 \times 10^{5} ; \triangle, 9.9 \times 10^{5} ; \square, 9.8 \times 10^{6}$.

(Fig. 3). With all inocula, however, the maximum increase in the number of bacilli was reached 8 weeks after inoculation. From the data in Fig. 3, a possible generation time of between 8 and 14 days can be calculated.

Effects of enzymic and chemical treatments of inoculum on the growth of bacilli. Bacilli suspended in sterile distilled water were treated with proteolytic enzymes (trypsin or pronase), and chemical agents (deoxycholate and petroleum spirit), under previously determined conditions in which infective activities were maintained for susceptible animals (Nakamura \& Ueno, I963; Nakamura, Imaizumi \& Komai, 1967). Each drop of suspension thus treated was smeared on a silicon-coated slide (Nakamura, 1967; 1973). This was incubated in NC-5 medium and the ensuing growth pattern was observed. All these treatments separated most of the bacilli from the crude material containing subcutaneous tissues. Among these treatments, the most significant effect on the morphological growth pattern of bacilli was obtained with pronase.

Multiplication of partially purified bacilli. Partially purified Mycobacterium lepraemurium had not lost their infective capacity when inoculated back into susceptible animals. Growth of such bacilli from two different starting populations was inoculated in NC-5 medium (Fig. 4). With a small number of bacilli as inoculum $\left(\mathrm{I} \cdot 5 \times 10^{5}\right)$ a smooth growth curve was obtained, whereas with a larger number of bacilli $\left(6 \cdot 4 \times 10^{6}\right)$ there was an indefinite growth pattern.

Effects of antibiotics. Additions of isoniazid at $1000 \mu \mathrm{g} / \mathrm{ml}$, streptomycin at $100 \mu \mathrm{g} / \mathrm{ml}$ and mitomycin $\mathrm{C}$ at $\mathrm{I} \mu \mathrm{g} / \mathrm{ml}$ at the time of inoculation of NC-5 medium inhibited multi- 


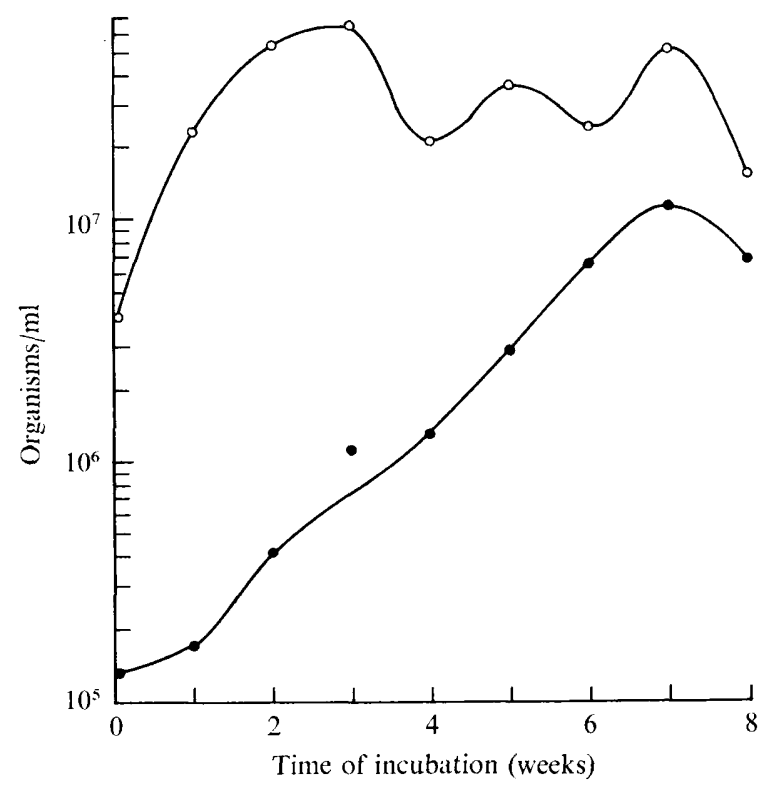

Fig. 4. Growth curves of partially purified Mycobacterium lepraemurium cultivated in NC-5 medium. Initial numbers of bacilli/ml culture medium were: $\bullet, 1 \cdot 3 \times 10^{5} ; 0,6 \cdot 4 \times 10^{6}$.

plication of bacilli throughout 60 days' incubation, whereas penicillin at 1000 units $/ \mathrm{ml}$ had no effect.

\section{Pathogenicity of cultivated bacilli}

$\mathrm{C}_{3} \mathrm{H}$ mice were subcutaneously inoculated with $0.2 \mathrm{ml}$ of well-shaken NC-5 medium in which bacilli were cultivated for $\mathrm{I} 2$ weeks at $30{ }^{\circ} \mathrm{C}$. Four months after inoculation, the mice were killed and a small leproma was found at the inoculation site. Bacteriological smears showed the presence of Mycobacterium lepraemurium; many bacilli were elongated and a lot of globi were present. No leproma and bacilli were seen on the smear made from the mice inoculated with a culture of EKP-goat serum medium cultivated under the same conditions as NC-5 medium.

\section{DISCUSSION}

Multiplication of Mycobacterium lepraemurium in the cell-free medium, referred to as $\mathrm{NC}-5$, was established by morphological observation and the increase in the number of bacilli as compared to the initial inoculum. Bacilli took 6 to 8 weeks to reach maximum numbers. Although growth was better at $30^{\circ} \mathrm{C}$ than $37^{\circ} \mathrm{C}, \mathrm{M}$. lepraemurium when in animals grows best in the internal organs, indicating a preference for $37^{\circ} \mathrm{C}$. This is unlike $M$. leprae which usually grows on the skin, thus indicating an optimum growth temperature of below $37^{\circ} \mathrm{C}$ (Shepard, 1965). Why goat serum was the most suitable among the sera tested for the promotion of growth is still not clear. Possibly, the serum might stabilize the $\mathrm{pH}$ of the medium during cultivation as well as acting as a nutrient. Generation times for growth of Mycobacterium lepraemurium were calculated as between 8 and 14 days and are in keeping with data obtained in tissue culture experiments (Garbutt, Rees \& Barr, 1962; Matsuo, 1970; Chang, Anderson \& Vaituzis, 1967).

As better growth rates were obtained with inocula of small numbers of bacteria, this 
suggested that carry-over of deleterious tissue fragments from the original source of the organism may have been occurring. Therefore, procedures for removing tissues from the inoculum were examined and, although pronase-treated bacteria gave a significant growth pattern, inocula of a large number of purified bacilli still gave an indefinite growth curve. Presumably, some auto-interference phenomenon of bacilli in the medium in the case of large inoculum could explain this observation. The NC-5 medium described here is still not completely satisfactory for growth of Mycobacterium lepraemurium as it fails to yield the abundance of bacteria which is a prerequisite for studying their biochemical properties.

This work was partially aided by a grant from the U.S.-Japan Cooperative Medical Science Program in 1972.

\section{REFERENCES}

Biberstein, E. L. \& Gills, M. (I96I). Catalase activity of Haemophilus species grown with graded amounts of haemin. Journal of Bacteriology 81, 380-384.

Chang, Y. T., Anderson, R. N. \& VAituZIs, Z. (1967). Growth of Mycobacterium lepraemurium in cultures of mouse peritoneal macrophage. Journal of Bacteriology 93, I I I9-I I3I.

GARBUTt, E. W., ReEs, T. J. W. \& BARR, Y. M. (1962). Growth of Mycobacterium lepraemurium maintained in cultures of rat fibroblasts. Journal of General Microbiology 27, 259-268.

KIRCHNER, O. (1932). Die Leistungsfähigkeit der Tiefenkultur des Tuberkelbazillus bei Verwendung besonders geeigneter flüssiger Nährboden. Zentralblatt für Bakteriologie, Parasitenkunde, Infektionskrankheiten und Hygiene (Abteilung I) 124, 403-4I 2.

Matsuo, Y. (1970). Multiplication of Mycobacterium lepraemurium in mouse foot-pad cell culture. Japanese Journal of Microbiology 14, 233-240.

Mori, T., Kosaka, K., Ito, T. \& Nishimura, S. (I96I). Collection method of murine leprosy bacilli. Japanese Journal of Bacteriology. 16, 808-813.

NAKAMURA, M. (1967). Improved method for observing elongation of Mycobacterium lepraemurium in vitro. International Journal of Leprosy 35, 505-509.

NAKAMURA, M. (1972). Multiplication of Mycobacterium lepraemurium in cell-free medium containing $\alpha$-ketoglutaric acid and cytochrome $c$. Journal of General Microbiology 73, 193-195.

Nakamura, M., (1973). Multiplication of Mycobacterium lepraemurium in cell-free liquid medium. Proceedings of the Japan Academy 49, 42-46.

Nakamura, M., Imaizumi, T. \& Komai, S. (1967). Isolation of Mycobacterium lepraemurium from infected tissues by petroleum ether treatment. Lepro 36, $137-139$.

Nakamura, M. \& Ueno, Y. (1963). A simple and sterile isolation method of Mycobacterium lepraemurium from infected tissues. Japanese Journal of Bacteriology 18, 75-79.

SHEPARD, C. C. (1965). Temperature optimum of Mycobacterium leprae in mice. Journal of Bacteriology 90 , $1271-1275$. 